\title{
Predictors of Survival for Patients with Non-small Cell Lung Cancer and Synchronous Brain Metastases with FDG-PET/CT Staging
}

\author{
N. Ohri \\ Thomas Jefferson University and Hospitals \\ Y. Xiao \\ Thomas Jefferson University and Hospitals \\ M. Werner-Wasik \\ Thomas Jefferson University and Hospitals
}

Follow this and additional works at: https://jdc.jefferson.edu/bodinejournal

Part of the Oncology Commons

Let us know how access to this document benefits you

\section{Recommended Citation}

Ohri, N.; Xiao, Y.; and Werner-Wasik, M. (2010) "Predictors of Survival for Patients with Non-small Cell Lung Cancer and Synchronous Brain Metastases with FDG-PET/CT Staging," Bodine Journal: Vol. 3 : Iss. 1 , Article 15.

DOI: https://doi.org/10.29046/TBJ.003.1.014

Available at: https://jdc.jefferson.edu/bodinejournal/vol3/iss1/15

This Article is brought to you for free and open access by the Jefferson Digital Commons. The Jefferson Digital Commons is a service of Thomas Jefferson University's Center for Teaching and Learning (CTL). The Commons is a showcase for Jefferson books and journals, peer-reviewed scholarly publications, unique historical collections from the University archives, and teaching tools. The Jefferson Digital Commons allows researchers and interested readers anywhere in the world to learn about and keep up to date with Jefferson scholarship. This article has been accepted for inclusion in Bodine Journal by an authorized administrator of the Jefferson Digital Commons. For more information, please contact: JeffersonDigitalCommons@jefferson.edu. 


\section{Predictors of Survival for Patients with Non-small Cell Lung Cancer and Synchronous Brain Metastases with FDG-PET/CT Staging}

\section{Ohri, N., Xiao, Y., Werner-Wasik, M.}

Department of Radiation Oncology, Thomas Jefferson University and Hospitals, Philadelphia, PA

\section{Purpose}

The clinical course of patients diagnosed with non-small cell lung cancer (NSCLC) with brain metastases (BM) at presentation is variable. Here we seek to identify predictors of survival in patients staged with FDG-PET/CT.

\section{Method and Materials}

We identified patients who were diagnosed with NSCLC with BM at presentation in the years 2007 or 2008 and underwent staging FDGPET/CT. Using a gradient-based semi-automatic contouring tool, hypermetabolic lesions were contoured on each patient's PET scan. Maximum SUV, number of hypermetabolic lesions (NHL), total metabolic tumor volume (MTV), and various clinical factors were evaluated as predictors of overall survival.

\section{Results}

Twenty-five consecutive patients with NSCLC and BM at presentation were identified. Of those, 15 patients $(60 \%)$ were alive 1 year after diagnosis, and 10 patients (40\%) are still alive with median follow-up of 26.4 months (range: 16.2-33.9). Patients alive at 1 year were younger at diagnosis (mean 53.2 v. 63.1 years, $\mathrm{p}=0.01$ ), had lower rate of extracranial metastases ( $7 \% \mathrm{v} .70 \%, \mathrm{p}<0.01)$, and had lower MTV (41.8 v. 115.7 cc, p=0.02) than other patients. Gender, presence of multiple BM, maximum SUV, and NHL were not significantly related to survival at 1-year. A multivariate Cox proportional hazards model demonstrated that increasing age and presence of extracranial metastases were significantly associated with decreased survival. Of patients younger than 65 without extracranial metastases at diagnosis, 12 out of $14(86 \%)$ were alive at 1 year.

\section{Conclusion}

A subset of patients diagnosed with non-small cell lung cancer with brain metastases can be expected to have a good prognosis. Further study is required to determine the prognostic significance of quantitative FDG-PET/CT findings. 